\title{
人吉の中国風紅茶伝習所の所在地について
}

\author{
熊本県県北広域本部農林水産部農業普及・振興課 ${ }^{*}$ \\ 坂本孝 義 ${ }^{\dagger}$ \\ つぼや履物店 \\ 益田啓三
}

(2018年10月24日受理)

\section{Study on the Location of the Chūgokufū Kōcha Denshūjo (Chinese Style Black Tea Training Center) in Hitoyoshi}

\author{
Takayoshi Sakamoto $^{\dagger}$ \\ Division of Agriculture Promotion of Northern Region Headquarters of Kumamoto Prefecture \\ Keizou Masuda \\ Tsuboya Footwear Store
}

Summary

The government of Japan, in the early Meiji era, established Chinese Black Tea Training Centers in several places, in order to promote the export of black tea by leveraging native tea (Yamacha). One of them, the Chinese Black Tea Training Center in Hitoyoshi was established in 1876 (Meiji 9). According to a document, it was located, in Tamachi, Hitoyoshi. A map of Tamachi between the late Meiji and the Taisho era revealed that the Chinese Black Tea Training Center had been near the Juhuku Brewery of today.

\section{1 諸 言}

幕末から明治にかけて茶は生糸とともに日本の重要な 輸出産物であったが、緑茶を嗜好するのは米国のみで、 他の国々は中国風の紅茶を嗜好していた。そこで世界に 向けては緑茶より紅茶に希望が持てるとのことから、紅 茶生産の施策が打ち出された。明治 7 (1874) 年には紅 茶製法書を編集し、各府県に配布して、紅茶の製造を 奨励した ${ }^{1)}$ 。また, 「明治 7 年に政府の勧業寮において, 中国人二人を招聘して試製したのが始まりである。当時,
輸出緑茶の価格がようやく下落し始めたことと, インド における紅茶産業の好況などに刺激され, 紅茶生産を企 図したもので」2) とあり, 輸出に向けた可能性への検 証が行われた。

一方，ヤマチャの定義は九州や四国等の山中に自生 する茶樹である ${ }^{3)}$ 。江戸中期の地理学者, 䇢妿势古松軒 （1726-1807）の記した山陽路から九州での紀行文『西遊 雑記』に, 人吉での一節には「淋しき山中にて茶のおび ただしく有るのみ」 ${ }^{4)}$ とある。既に江戸時代半ばにヤ マチャが繁茂していたことが記されており，これがヤマ チャを記録した最初のものと思われる。さて,『日本茶 
業史』に「肥後の玖摩，八代，山鹿‥等に，自生の茶繁 茂するもの眇からず」 ${ }^{5)}$ と, 熊本にはヤマチャが豊富 であると記されている。

そこで，豊富なヤマチャを開発利用し紅茶を生産して 輸出を奨励しようと，1875（明治 8）年には政府が中国 人の技術者 2 人（凌長富、姚秋桂）を招き熊本県鹿本郡 山鹿町（山鹿市）と大分県大野郡元西山村ノ内木浦（佐 伯市（旧宇目町））に国内で初めて中国風紅茶伝習所を 設け，翌年には熊本県球磨郡人吉町（人吉市）にも伝習 所を設けている ${ }^{6)}$ が，人吉についてはその所在地が推 測されたので本稿で報告する。

\section{2 人吉の紅茶伝習所}

『明治前期農業事蹟書』には、人吉の紅茶伝習所につ いて「第一四大区四小区田町の得田丈吉家作を借り入れ て」 ${ }^{6)}$ とあり, 住所が判明している。ところで「田町 の得田丈吉」の家はどこにあったのかを特定するため, 絵図を求めて熊本県立図書館の郷土資料室を訪ねた。資 料室では, 江戸時代は熊本城下など一部の地域で武士の 住宅は住所を特定できるが, 町民の住宅になると滅多に は記録に残っていないという。地図は戦争に利用された りするなど軍事機密のひとつと思われたので一般には出 回っていなかったし, 出回っていたとしても数も少なか った。しかも地図が一般的に作られるようになったのは 戦後からのことで, 住宅地図ならなおさらのこと, 作ら れるようになったのは昭和時代の後半からという回答だ った。

郷土資料室には明治前期の記録は残されていなかった ので, 明治末期から大正時代初期の人吉市田町を記した 地図を参照した（図1）。
参照した人吉市田町の地図には『昭和60年春, 新井茂 徳，本郷保男』との記載があり，それに続いてそれぞれ 87，83という数字がある。1985（昭和60）年にそれぞれ 87歳, 83歳であったということが推測できる。

これによると得田丈吉の家は, 徳田常次郎の家と推定 される。その根拠として田町にはトクダと名乗るのは徳 田常次郎だけであり，1793（寛政 5 ）年の町奉行日記で ある『新宮庄大夫行雄覚書』によると徳田は江戸時代に は「得田」と名乗っていた。同日記によると「田町乙名 徳田丈吉名字文字得田と改申度旨願出申上候処, 其通申 渡候様被仰渡候事」7) とある。同日記に書付をもって 同じ字を使わず，他の文字に変えるよう指導がなされて いるので, 相良藩32代藩主相良頼徳と同じ「徳」の字を 使用することが憚れたと考える。また, 徳田常次郎が『す・ 酒』を生業としていていたことに加え, 徳田常次郎のと ころに『寿福』という文字が地図に確認できる（図 2) ので, 現在の寿福酒造の関係者が紅茶伝習所について知 るものと推察される。

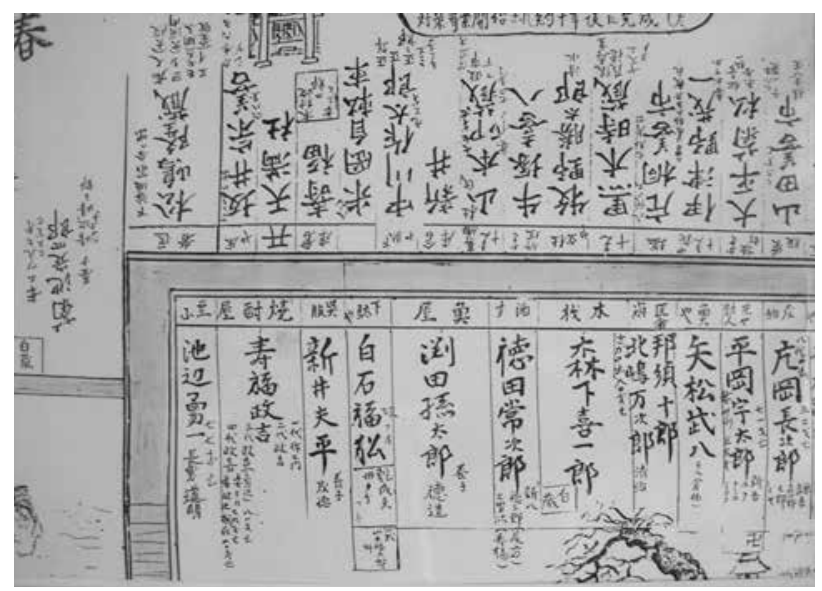

図 2 明治末期〜大正期の人吉市田町（寿福酒造付近）

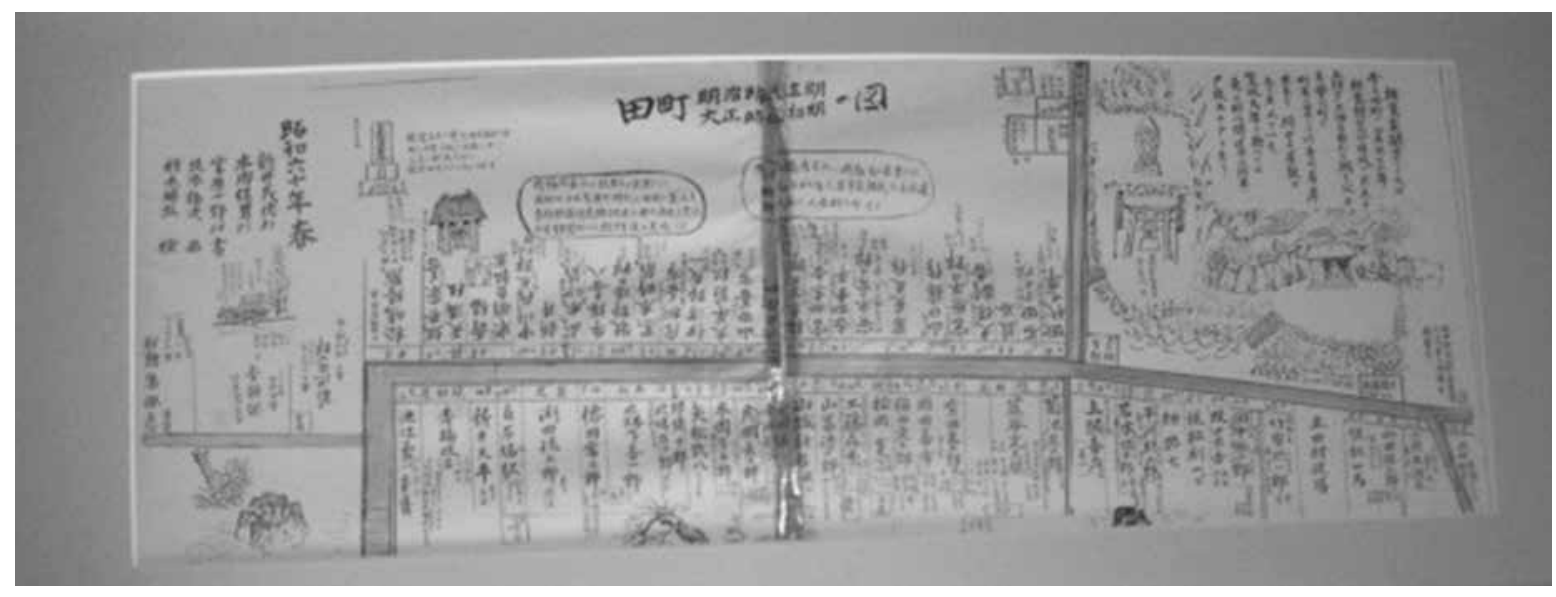

図 1 明治末期 大正期の人吉市田町の全景 


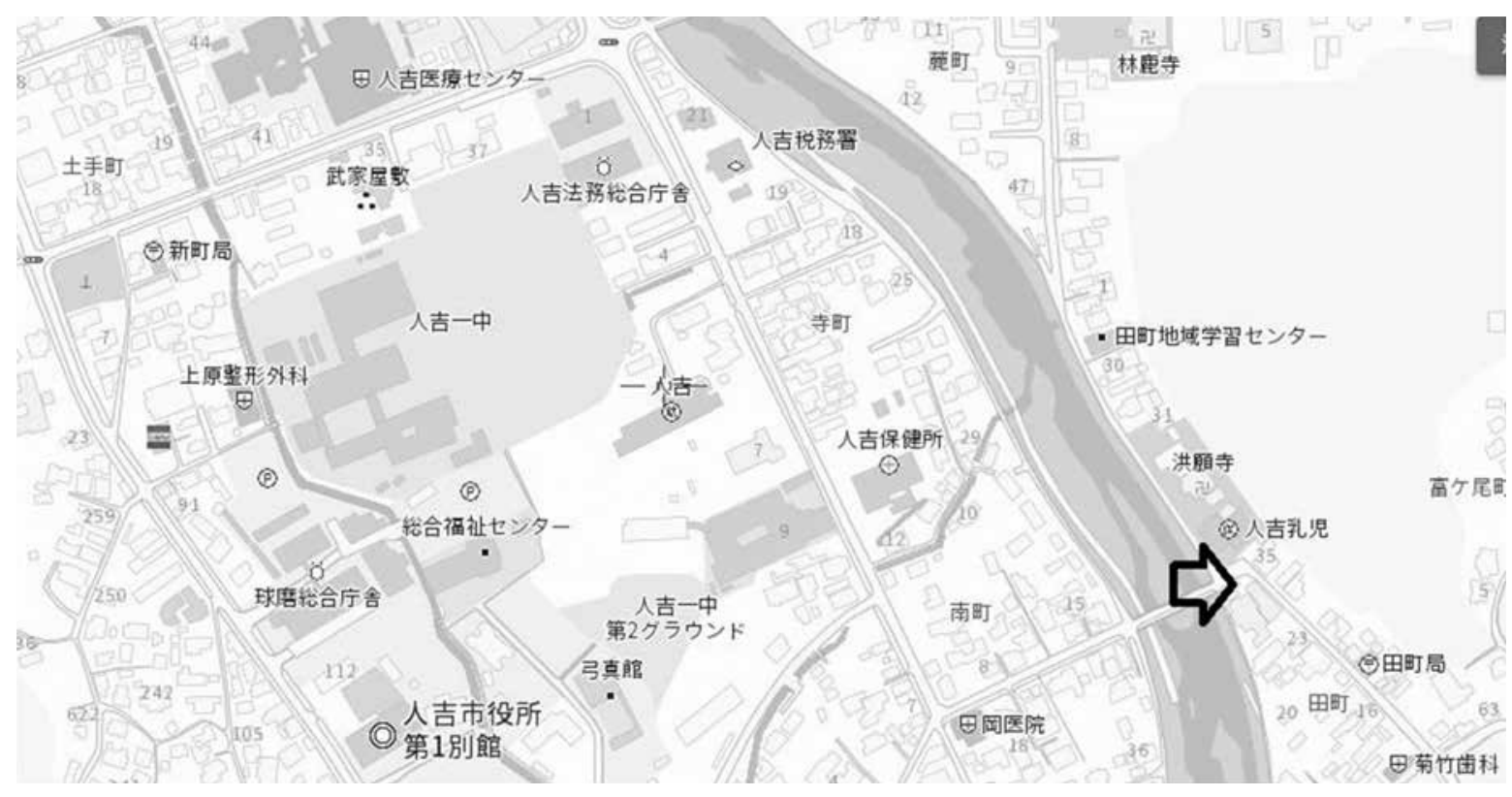

図 3 現在の人吉市田町（矢印は寿福酒造）

寿福酒造の寿福絹子氏（昭和 23 年生まれ）によると, 戦後に河川改修が行われ当時の様子が失われたものの, 徳田家は現在の寿福酒造の数軒右隣りに当たり, 矢岳に 茶園を所有していたこともあり紅茶の事業に関わったの ではないかとは語る。これらのことから人吉紅茶伝習所 の所在地は現在の人吉市田町にある寿福酒造の数軒右隣 りであることがわかった（図 3 )。

さて，紅茶伝習所は1876（明治 9 ）年 5 月末から 8 月 まで設けられたが，試作した中国風紅茶の評価は芳しく なかった ${ }^{6)}$ 。伝習所に招請された中国人は安徽省の緑茶 の専門家で，紅茶の技術者ではなかった ${ }^{1,8)}$ という。外 国に輸出できるような上質の紅茶が製造できなかったの も当然である ${ }^{8)}$ と記載されている。試作した中国風紅 茶が芳しい評価が得られなかった一方で，インド風紅茶 は海外で高い評価を得たので，1878（明治11）年，内務 省は紅茶製造伝習規則を発布、一府三県に設置された紅 茶伝習所はインド風紅茶であった ${ }^{9)}$ と記載されている。

\section{3 摘 要}

明治初期に政府はヤマチャを利用して紅茶の輸出振興
を図るために, 各地に紅茶伝習所を設置した。このうち, 1976（明治 $9 ）$ 年に設立された人吉の中国風紅茶伝習所 は，文献に人吉市田町であることが記されている。明治 末期から大正期を記した人吉市田町の地図によると, 紅 茶伝習所は現在の寿福酒造近辺であることが明らかにな った。

\section{4 引用文献}

1 ）全日本紅茶振興会（2003）：紅茶百年史. 文生書院, pp.5-12.

2 ) 曽根俊一 (1976)：食の科学, No.28, (財)農政調查委員会, p.20.

3 ）日本茶業技術協会（2007）：茶の科学用語辞典, pp.116.

4 ）宮本常一（1969）：日本庶民生活史料集成 第 2 巻 探検 - 紀 行・地誌 (西国篇), 三一書房, pp.367-368.

5 ）茶業組合中央会議所(1914)：日本茶業史, pp.2-3.

6 ）農林省農務局（1939）：明治前期勧農事蹟輯録 下巻, pp.12741277.

7 ) 新宮庄大夫行雄覚書（個人蔵）

8 ) 川口国昭 (1989): 茶業開花 明治発展史と多田元吉. 山童社, p.80.

9 ）日本茶輸出百年史編纂委員会（1964）：日本茶輸出百年史. 日 本茶輸出組合, pp.53-66. 